\title{
Gatunek mowy: zamknięty system cech, tekst otwarty, czy kategoria poznawcza?
}

\section{Przemyslaw Lozowski}

Uniwersytet Technologiczno-Humanistyczny im. Kazimierza Pułaskiego w Radomiu p.lozowski@uthrad.pl

\section{Marta Wójcicka}

Uniwersytet Marii Curie-Skłodowskiej w Lublinie marta.wojcicka@ poczta.umcs.lublin.pl

\section{Streszczenie}

Artykut stanowi próbę odpowiedzi na postawione $w$ tytule pytanie. Puntem wyjścia jest przeglad językoznawczych koncepcji gatunku mowy o nachyleniu strukturalnym, funkcjonalnym, wreszcie kognitywnym oraz próba odniesienia kognitywnej koncepcji prototypu Ronalda Langackera do wyżej wymienionych ujęć wyrostych na gruncie polskiej tekstologii. Jako egzemplifikacja analizowanych koncepcji gatunku służa dwie wspótczesne wersje o Kopciuszku. Na ich przykładzie autorzy staraja się odpowiedzieć na pytanie, dlaczego należa do gatunku bajki $w$ świetle przywolywanych koncepcji oraz co nowego, w zakresie genologii, przynieść może aplikacja koncepcji Ronalda Langackera

Słowa kluczowe: gatunek tekstu, bajka magiczna, wzorzec strukturalny, baza doświadczeniowa

\section{Abstract}

Genre of Speech: A Closed System of Features, an Open Text or Cognitive Category?

The article revolves around the title question, starting with a brief overview of the major accounts of what the speech genre can possibly be in structurally, functionally-, and, finally, cognitively-oriented accounts. The latter are identified specifically with Ronald Langacker's understanding of the prototype, and are here related/compared to the conceptions in selected Polish genre studies. The material basis and the source of exemplification are found in two modern versions of the Cinderella story. The main bulk of argumentation has to do with the research question of why, how, and to what extent these two modern versions can still be considered a Cinderella tale in the light of the respective accounts, and what new perspectives Langacker's conception of the prototype can bring if applied to speech genre studies.

Key words: speech genre, magic fairy-tale, structural pattern, experiential baseline 


\section{Wstęp}

Pojęcie „gatunku” określić można jako należące do tzw. leksyki ogólnonaukowej. Jest to bowiem kategoria typologiczna wykorzystywana w klasyfikacjach biologicznych, etnologicznych, antropologicznych oraz w szeroko rozumianej humanistyce. Punktem wyjścia do artykułu jest przegląd językoznawczych koncepcji gatunku mowy

${ }^{1}$ o nachyleniu strukturalnym, funkcjonalnym, wreszcie kognitywnym oraz próba odniesienia kognitywnej koncepcji prototypu Ronalda Langackera do wyżej wymienionych ujęć wyrosłych na gruncie polskiej tekstologii.

W każdym przypadku materiałem ilustracyjnym są dwie bajki o Kopciuszku (teksty w tabeli 1 poniżej) - na ich przykładzie odpowiemy na pytanie, dlaczego należą do gatunku bajki w świetle przywoływanych koncepcji.

Tabela 1. Zestawienie materiału ilustracyjnego dla dwóch wersji bajki o Kopciuszku

\begin{tabular}{|c|c|}
\hline Tekst A & Tekst B \\
\hline 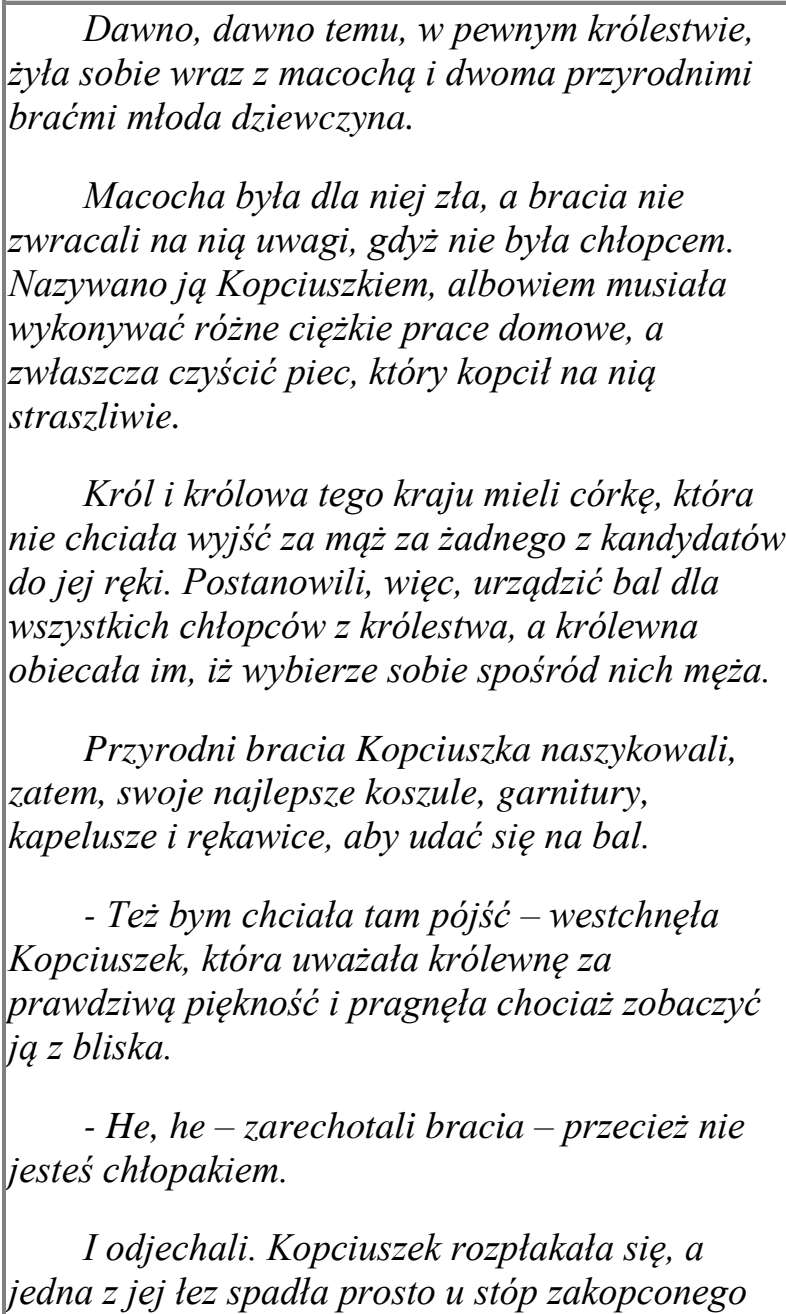 & $\begin{array}{l}\text { Dawno, dawno temu żyli sobie szczęśliwi Hip } \\
\text { Hopowcy. Mieli córke jedynaczkę, która także byta } \\
\text { fanka Hip Hopu. Przez wiele lat wiodto im się } \\
\text { doskonale, a dom rozbrzmiewat ich ulubionq muzyka. } \\
\text { Niestety, pewnego lata matka dziewczynki ciężko } \\
\text { zachorowała i po tygodniu zmarła. Kilka dni po } \\
\text { pogrzebie tata dziewczynki znalazt sobie inna } \\
\text { towarzyszkę życia, która miała dwie, nieróżniace się } \\
\text { charakterem od matki córki. Macocha zawsze miata dla } \\
\text { niej prace i nie dawata dziewczynce chwili odpoczynku: } \\
\quad \text { - Ej, niezguto, idź zrobić mi stronę internetowa! } \\
\quad \text { - Ty, Kopciuchu, już do wieży stereofonicznej, masz } \\
\text { mi właczyć Country! } \\
\quad \text { - Co się gapisz, do pracy! } \\
\quad \text { Po kilku dniach nawet jej własny ojciec zacząt } \\
\text { nazywać ja Kopciuszkiem, a ona sama zapomniała } \\
\text { swojego prawdziwego imienia. } \\
\quad \text { Pewnego razu rozeszła się wieść o DJ, który } \\
\text { znudzony samotnym życiem szuka matżonki. By tego } \\
\text { dokonać będzie codziennie organizowat dyskoteki, na } \\
\text { których znajdzie sobie odpowiednia dla siebie żonę. } \\
\text { Gdy córki macochy dowiedziaty się o DJ poszukującego } \\
\text { żony i o dyskotece o 20.30 od razu zaczęty się ubierać i } \\
\text { stroić }\end{array}$ \\
\hline
\end{tabular}


kominka. I nagle... w tym właśnie miejscu pojawita się najlepsza przyjaciótka jej zmartej mamy-dobra wróżka.

- Nie martw się, Kopciuszku, pójdziesz na bal - pocieszyła dziewczynę.

- Ale jak? - zdziwita się Kopciuszek Przecież nie jestem chtopcem i nie mam nawet męskich ubrań, a ubrania moich braci sq na mnie o wiele za duże.

- To najmniejszy problem - roześmiała się wróżka i jednym machnięciem czarodziejskiej różdżki zmieniła stara sukienkę Kopciuszka w elegancki dwuczęściowy garnitur, jej czepek w szykowny kapelusz, a jej spracowane dtonie pokryły jedwabne rękawice. - Tylko pamiętaj dodała wróżka - o pótnocy czar pryśnie i znów będziesz ubrana w swoja sukienkę.

- Będę uważać, dziękuję! - zwotata uszczęśliwiona dziewczyna, odjeżdżając wyczarowana przez wróżkę karoca.

Tymczasem, na balu, królewna nudzita się śmiertelnie, a jej rodzice popadali $w$ czarna rozpacz, widzac, że córka nie tańczy z żadnym, zaproszonym na tę okazję mtodzieńcem. Aż tu nagle, na sale $z$ wdziękiem weszła ubrana po męsku Kopciuszek.

Od momentu, gdy królewna ujrzała ją, nie rozstały sie już ani na chwile, przetańczyly razem cała noc. Ich whosy splataty się $w$ tańcu.

Kopciuszek ustyszała nagle, iż zamkowy zegar wybija pótnoc. Korzystając z chwilowej nieobecności królewny, uciekła po schodach, gubiac na nim jeden z trzewików. Przez cała droge do domu mocno ptakała, gdyz rozstanie z piękna księżniczka przyprawito ja o ogromny smutek.

Kiedy zaś ta zauważyła zniknięcie i znalazła bucik, zapowiedziała swoim rodzicom, iz nie poślubi nikogo innego, jak jego tajemniczego wtaściciela. Rozkazano, zatem, odszukać tę osobę. Straże objechaty domy wszystkich młodych mężczyzn w królestwie, trzewiczek byt jednak na nich wszystkich zdecydowanie za maty.

Ostatni w kolejce byt dom Kopciuszka i jej braci. Kiedy nie udało się im wcisnać swoich stóp do bucika (a chętnie zostaliby mężami królewskiej
Akurat wtedy przechodził obok pokoju Kopciuszek i ustyszat, o czym mowa. Dziewczynka wiedziała, że macocha nie pozwoli jej iść na dyskotekę, więc nawet jej o tym nie wspomniała by jej zbytnio nie rozzłościć.

Gdy macocha wychodzita już ze swoimi córkami na dyskoteke, Kopciuszek nie wytrzymat i spytat:

- Moge iść na dyskotekę, proszę!

- Co? Chyba ci odbiło, nie masz w co się ubrać, a poza tym nie dokończyłaś jeszcze strony internetowej! powiedziała macocha mokra ze złości.

Dziewczynka spuścila glowę $i$ wróciła do komputera. Po chwili pracy przy komputerze ustyszata cichuteńkie szeptanie.

- K-k-k-kto-o-o t-t-o-o-o? - zapytata przestraszona.

- To ja, super-informatyk! - powiedziat pan stojacy w oknie - Mam dla ciebie piękny strój dyskotekowy. Szybko, przebieraj się i zmykaj na zabawę, a ja napisze za ciebie ta stronę internetowa!

Kopciuszek oniemiał z radości i od razu przymierzyt strój. Byt doskonaty i odpowiadat tamtejszej modzie:

$$
\begin{aligned}
& \text { biała krótka bluzka; } \\
& \text { czarna spódniczka; } \\
& \text { czarne szpilki do kolan; } \\
& \text { przeźroczyste okulary. }
\end{aligned}
$$

Dziewczynka ucałowata super-informatyka w policzek i pobiegła na dyskotekę. Super-informatyk krzyknąt tylko jeszcze do Kopciuszka, że musi wrócić przed godz. 24.00, bo inaczej strój zniknie.

Gdy Kopciuszek wkroczył za próg drzwi muzyka ucichta, a DJ urzeczony uroda pięknej nieznajomej, czym prędzej poprosit ja do tańca. Nastawit gramofony i dograt tempa obu plyt w 3 sekundy. Przez caty wieczór DJ nie odstepowat jej na krok. Dziewczyna nawet nie myślała wrócić do domu, ale gdy wybiła godzina 24.00 Kopciuszek odwrócit się i nic nie mówiąc wybiegt z sali. Macocha i siostry wrócity z dyskoteki rozwścieczone i naburmuszone.

- Jak on na nia patrzyt - mówity.

- O kim mówicie siostry? - zapytał kopciuszek 
(córki!), dat się styszeć za plecami straży $i$ królewny cichy głos:

- Pozwólcie i mnie go przymierzyć.

Straże roześmiały się na widok Kopciuszka, królewna jednak poznała jej głos i rozkazała im podać dziewczynie trzewik. Pasowat idealnie na jej drobna stopę. Kopciuszek zdjęła niewdzięczny czepek sprzątaczki. Zalśnity jej złote loki.

Wówczas królewna była już pewna, kto przed niq stoi.

Uradowana, wzięta Kopciuszka w ramiona $i$ zabrała ze soba do zamku rodziców. Ci zaś, uszczęśliwieni, że ich córka znalazła wreszcie miłość swojego życia, wyprawili dziewczynom piękny ślub. Oraz wesele, na którym każdy mógt bawić się i tańczyć, z kim tylko chce.

(http://www.etykawszkole.pl/baza-wiedzy/materiay-edukacyjne/280-bajka-o-kociuszkucakiem-inaczej $z d n$. 17.09.2016).
- Nie twój interes, smoluchu! Zrobiłaś, co ci nakazałam?

Jakiez było zdumienie macochy, gdy zobaczyła piękna stronę internetowa z kilkoma hipertaczami. Gdy macocha wychodziła następnego wieczoru na dyskoteke powiedziata do Kopciuszka:

- Tym razem tak łatwo się nie wywiniesz, mój kopciuchu. Masz tu trzy gry komputerowe dla moich córeczek, i masz mi je zainstalować. Po wyjściu macochy $z$ domu super-informatyk pojawit się w oknie.

-Nie mamy czasu! Ubieraj się szybko i na dyskoteke!! Ja to już zainstaluje.

Kopciuszek bawit się doskonale. DJ tańczyt wybornie. Gdy wybita 24.00 dziewczynka wybiegła z dyskoteki ile sit w nogach. DJ nie chciat jej wypuścić, ale ona wyrwata mu się z rak. Biedny i zasmucony $D J$, już miat wrócić na dyskotekę, gdy zobaczyt na schodach coś czarnego. Podbiegt szybko $i$ wziat do ręki. Okazato się, że to but pięknej nieznajomej. Uradowany DJ zamyślit się i powiedziat:

- Odnajde ja, odnajdę. Nawet gdyby miało mi to zająć całe życie!

Jak powiedziat tak zrobit. Nastęnego dnia rozpoczą poszukiwania. Wieść o zakończeniu dyskotek bardzo szybko rozeszła się po wsi. Gdy kopciuszek dotart do domu macocha ze swymi córkami juz tam były. Rozzłoszczona wdowa zagonita kopciuszka do komórki. Dziewczyna siedziała tam cały dzień.

Wieczorem, po zachodzie stońca zadzwonit dzwonek do drzwi. To DJ z bucikiem Kopciuszka. Córki macochy zaczęty się przepychać, która z nich przymierzy pierwsza. Niestety, ale żadna z szerokich $i$ grubaśnych nóg dziewczynek nie zmieściła się do buta.

Gdy DJ wychodził z mieszkania ojciec Kopciuszka powiedziat:

- Mamy jeszcze jedna córkę!

DJ znów blysnąt nadzieja. Tata poszedt po córkę, a ona bez problemu włożyta swoja stopę do buta.

Nastepnego dnia odbyto sie wielkie wesele. Kopciuszek i DJ żyli dlugo i szczęśliwie. (http://sciaga.pl/tekst/89555-90nowoczesna_wersja_kopciuszka z dn. 16.09.2016). 


\section{Gatunek w językoznawstwie strukturalnym i funkcjonalnym: od systemu do tekstu}

Przegląd polskiej literatury przedmiotu pozwolił na wyróżnienie następujących dominujących ${ }^{2}$ koncepcji gatunku mowy.

\subsection{Gatunek jako normatywny, zamknięty system}

Gatunek mowy ujmowany jest jako swoista gramatyka literatury, normatywny zestrój dyrektyw (Głowiński 1967). Porównywany jest do systemu językowego i, podobnie jak system językowy umożliwia formułowanie wypowiedzi, gatunek - jako utrwalony intersubiektywnie zespól wskazań, czynników i środków - umożliwia dany sposób mówienia (Głowiński 1967: 92). Jednocześnie - podobnie jak system gramatyczny - konwencje gatunkowe nie uniemożliwiają jednostkowej ekspresji. „Sposób odnoszenia się do zastanych uporządkowań, gatunkowa instrumentacja tekstu stają się śladem jednostkowych decyzji, dokumentem wyborów dokonywanych przez podmiot" (Grochowski 2004: 24). W takiej koncepcji gatunku mowy podkreśla się, że stosunek konkretnego tekstu do gatunku jest taki sam, jak stosunek parole do langue w klasycznej terminologii de Saussure'a (Głowiński 1967: 92). Relacja ta określana jest jako gra konieczności i możliwości (Głowiński 1967: 88). Gatunek - znowu podobnie do systemu językowego - ma więc wymiar społeczny, czyli sprzyja (lub przeciwdziała) poczuciu wspólnoty „tekstowego świata” (Balcerzan 1999: 7).

Podstawę porównania gatunku do systemu językowego stanowią następujące cechy wspólne: charakter społeczny, abstrakcyjne, potencjalne i powtarzalne zasady organizacji tekstu, decydujące o jego morfologii ,podporządkowanych jakimś celom komunikacyjnym i zdeterminowanych przez materiał oraz technikę przekazu (medium)” (Balcerzan 1999: 10). Takie ujęcie gatunku inspirowane jest koncepcją Michaiła Bachtina, który reguły gatunkowe przyrównywał do reguł gramatycznych (syntaktycznych) (Bachtin [1979]1986).

Tę systemowość gatunku - jego potencjalność, zamkniętość i strukturalność - wyraźnie widać na przykładzie funkcjonowania tekstów folkloru, które - jak podkreśla Jerzy Bartmiński

mają swój aspekt strukturalny i byt potencjalny. Będąc sekwencją zdań rozciągłą w czasie i procesualną, jest równocześnie całością zorganizowaną wedle właściwego sobie paradygmatu i zintegrowaną jako pewna całość. W folklorze ta całość jest rozpoznawana w procesie reprodukcji połączonej zawsze z przystosowaniem do sytuacji nadawczo-odbiorczej 
(Bartmiński 1992: 251)

Gdybyśmy mieli teraz powiedzieć, dlaczego dwa teksty cytowane w tabeli powyżej, należą do gatunku bajki, musielibyśmy wskazać leżący u ich podłoża wzorzec gatunkowy. W obu tekstach - w myśl strukturalistycznej koncepcji bajki Władimira Proppa - pokazać można stałe, powtarzalne elementy, ważne ze względu na rozwój akcji. Propp zauważył, że bajki magiczne odznaczają się jednorodną, szczególną, właściwą tylko dla niej kompozycją, będącą ich wyróżnikiem. Dokonana przez Proppa analiza stu tekstów bajkowych pozwoliła mu na wydzielenie trzydziestu jeden funkcji postaci działających oraz siedmiu ról: bohater, fałszywy bohater, osoba wysyłająca bohatera w świat, przeciwnik (antagonista), donator, pomocnik, ofiara - królewna lub jej ojciec (Propp [1928]1976). Funkcję bajkowych bohaterów określił jako działanie z punktu widzenia roli, jaką odgrywa on w przebiegu akcji (Propp 2000: 92). W analizowanych przykładach występują: bohaterka (Kopciuszek), ofiara (królewna - w wersji A, DJ - w wersji B), antagonista - macocha i jej synowie (A) lub córki (B), donator (wróżka B, super-informatyk - B). W wyniku analizy morfologicznej Propp wskazał trzydzieści jeden funkcji postaci działających, które odpowiadają głównym etapom akcji. W analizowanych tekstach wskazać można następujące: odejście, zakaz, naruszenie zakazu, wspomaganie, szkodzenie (lub brak kogoś lub czegoś), rozpoczynające się przeciwdziałanie, wyprawa, pierwsza funkcja donatora, reakcja bohatera, przekazywanie magicznego środka, przemieszczenie przestrzenne, rozpoznanie, transfiguracja oraz wesele (Propp 1976). Propp zauważył, że układ funkcji stanowi kompozycję bajki (Propp 2000: 92). Istotny kompozycyjne i rozpoznawalny element bajki stanowią formuły ramowe. Oba teksty zawierają inicjalne egzystencjalne wyrażenie formuliczne ${ }^{3}$ (A: Dawno, dawno temu, w pewnym królestwie, żyła sobie wraz z macocha i dwoma przyrodnimi braćmi młoda dziewczyna; B: Dawno, dawno temu żyli sobie szczęśliwi Hip Hopowcy. Mieli córke jedynaczkę, która także była fanka Hip Hopu) oraz finalne egzystencjalne WF (A: Ci zaś, uszczęśliwieni, że ich córka znalazła wreszcie miłość swojego życia, wyprawili dziewczynom piękny ślub. Oraz wesele, na którym każdy mógt bawić się i tańczyć, z kim tylko chce; B: Następnego dnia odbyło się wielkie wesele. Kopciuszek i DJ żyli długo i szczęśliwie).

Zgodnie z opisanym przez Proppa paradygmatem bajki magicznej, elementami stałymi gatunku są funkcje postaci działających oraz ich role, natomiast pozostałe elementy - w tym „wypełnienie” funkcji - są zmienne. Oba teksty realizując paradygmat bajki, jednocześnie jak langue - stanowią przykład przystosowania znanej bajkowej fabuły do aktualnych sytuacji 
społeczno-kulturowych, stąd następuje zmiana charakterystyki bohaterów (fanka Hip Hopu, DJ, księżniczka poślubiająca Kopciuszka zamiast księcia). Wzorzec gatunkowy bajki magicznej wykorzystano w powyższych tekstach w sposób twórczy i dydaktyczny dla ukazania świata miłości homoseksualnej (A), uaktualniono dawną klasyczną wersję bajki, by stała się bliższa współczesnym realiom (dyskoteka zamiast balu w wersji B). Oba teksty stanowią zatem - używając nomenklatury Głowińskiego - przykład gry konieczności realizowania konwencji gatunkowej bajki magicznej oraz możliwości jej transformacji w taki sposób, by powiedzieć coś o dzisiejszym świecie. Oba teksty powstały więc na bazie znanego, rozpoznawalnego wzorca strukturalnego, a to pozwala zakwalifikować je jako bajki magiczne. Indywidualne realizacje tego wzorca oraz przekształcenia, które jednak nie zmieniają morfologii bajkowych tekstów, stanowią warianty tekstu bajki o Kopciuszku.

\subsection{Gatunek jako struktura dynamiczna}

Obok ujęcia gatunku jako zamkniętego systemu, głównie na gruncie literaturoznawstwa, pojawiły się głosy ukazujące gatunek jako strukturę o charakterze dynamicznym (Trzynadlowski 1962). Mimo teoretycznych pozorów stabilności gatunek jest zjawiskiem ulegającym nieustannym zmianom, które polegają „na wariancyjności zasad zależnie od tematyki, problematyki, funkcji artystycznych i ideowych, okresu historycznego i podporządkowanych im prądów, kierunków i szkół” (Trzynadlowski 1962: 46). Trzynadlowski wyróżnia dwie kategorie względnie stałych elementów, które składają się na gatunek tekstu. Są to formy stosunku twórcy do opisywanego czy przetwarzanego przedmiotu (,sposób widzenia świata”) oraz formy kształtujące to konkretne widzenie (,sposób kształtowania owego widzianego świata").

Przywołane w tabeli, funkcjonujące np. w przestrzeni internetu realizacje znanych bajek ludowych ukazują punkt widzenia głównie młodych ludzi, którzy wybierają z worka tradycji to, co ponadczasowe, to co stanowi o istocie gatunku (np. bajki magicznej). Opowieści takie są przykładem transformacji tradycyjnego tekstu folkloru. Są dialogiem z różnego rodzaju tradycjami, próbą zabawy konwencją gatunkową.

Przywołane przykłady pokazują jednocześnie, że gatunek (np. bajki magicznej) stanowi „kulturowo i historycznie ukształtowany oraz ujęty w społeczne konwencje sposób językowego komunikowania się” (Gajda 2001: 255), stąd pojawienie się współczesnych, często wręcz kolokwialnych, wyrażeń (np. fanka Hip Hopu, wieża stereofoniczna, chyba Ci odbiło...) 
Gatunek jako pewien wzorzec zawiera nie tylko kategorie formalnojęzykowe, ale także dotyczące poznania (kognitywne) - mniej lub bardziej uporządkowany obraz świata i pewną hierarchię wartości, jak również pragmatyczne - pewne charakterystyki użytkowników wraz z zamiarami ich działań (Gajda 2001: 256). Gatunek jest więc określany jako „wzorzec idealny, pewien uogólniony model, który zawiera właściwości jądrowe, kanoniczne” (ŻydekBednarczuk 2001: 122). Jest to „twór abstrakcyjny (model, wzorzec) mający jednak różnorodne konkretne realizacje w formie wypowiedzi, a także zbiór konwencji, które podpowiadają członkom określonej wspólnoty komunikatywnej, jaki kształt nadać konkretnym interakcjom" (Wojtak 2004: 16). Jako model/wzorzec stanowi abstrakcyjny, ale też zamknięty zbiór konwencji, które jednak mogą być modyfikowane i dostosowywane do aktualnej sytuacji wykonawczej. Gatunek określić więc można jako zamknięty wzorzec, ale jego tekstowe realizacje są otwarte na sytuację.

Oba przykłady (teksty A i B powyżej) stanowią przykład tak rozumianego gatunku. Bez wątpliwości zakwalifikować je można do bajek magicznych z tego względu, że wyraźnie odwołują się do zamkniętego zbioru konwencji bajkowych, a jednocześnie owe konwencje przybierają kształt zrozumiały dla współczesnego, młodego odbiorcy. Oba teksty realizują nie tylko wzorzec strukturalny bajki magicznej, ale także uobecniony w gatunku światopogląd. Dzięki specjalnemu doborowi stereotypowych tematów, sytuacji i bohaterów klasyczna bajka stanowi wyraz marzeń i pragnień człowieka o lepszym, dostatnim życiu (Ługowska 1981: 16). Główną zasadą semiotycznej organizacji tematu jest konstruowanie wizji rzeczywistości intencjonalnej, która odpowiada marzeniom człowieka. Obrazuje ona prawa zgodne z ludowym poczuciem sprawiedliwości i moralnego ładu świata (Ługowska 1981: 23). Bajka magiczna pełni więc funkcje kompensacyjne, bowiem jej intencją jest dostarczenie moralnej satysfakcji z powodu rozwoju wydarzeń w oczekiwanym przez słuchacza kierunku. Jest to gatunek intencjonalnie związany z ukazywaniem lepszego świata (Ługowska 1993: 35-36). ${ }^{4}$ Lepszy, sprawiedliwszy świat to świat, w którym dobro zostaje wynagrodzone (pomiatana i pogardzana bohaterka wychodzi za mąż za DJ-a - tekst B) oraz taki, w którym każdy mógt bawić się i tańczyć, z kim tylko chce (tekst A).

\subsection{Gatunek jako otwarty, kontekstowy komunikat}

W innych ujęciach (np. Stefanii Skwarczyńskiej 1954) gatunek - w odróżnieniu od koncepcji Głowińskiego - to nie system, nie wzorzec, ale zmienny (a więc i otwarty) komunikat językowy. Otwarty charakter gatunku wynika z jego czynników konstytutywnych, którymi są: 
nadawca, odbiorca, stosunek łączący nadawcę z odbiorcą, sytuacja: nadawcza, odbiorcza, nadawczo-odbiorcza, funkcja i przedmiot komunikatu, ujęcie przedmiotu komunikatu, tworzywo komunikatu, przedstawienie i wyraz oraz kod. Otwartość gatunku wynika więc z jego procesualności oraz intertekstualności (Duszak 1998: 218-219).

Otwarty charakter gatunku definiowanego jako komunikat/tekst wynika $\mathrm{z}$ trzech czynników:

1) procesualnego charakteru, który powoduje dostosowanie realizacji do sytuacji wykonawczej (otwartość na sytuację): „Gatunek nie stanowi sumy cech, które dałoby się wyliczyć w postaci zamkniętego katalogu wyznaczników, nie jest redukowalny do jakichkolwiek dyrektyw formalnych (choć sam je niekiedy wymusza), nie należy do mechanizmów stricte tekstotwórczych [...] Jest natomiast regulatorem odbioru, identyfikującym daną wypowiedź w aspekcie funkcjonalnym i odpowiednio modyfikującym zawarte w niej treści” (Grochowski 2004: 23);

Przywołane przykłady świadczą o tym, że teksty te nie są jedynie realizacją dyrektyw bajkowych, są świadectwem odbioru tradycyjnej fabuły i jej modyfikacji pod kątem potrzeb i wyzwań współczesności. Jednocześnie, te zmodyfikowane teksty, wykorzystujące „znany na całym świecie wątek bajek magicznych o pięknej i dobrej dziewczynie wykorzystywanej w roli służącej przez macochę i przyrodnie siostry (lub braci - wersja A), która po wielu perypetiach zostaje żoną księcia (księżniczki w tekście A lub DJa w wersji B) (Rzepnikowska 2017: http://bajka.umk.pl/slownik/lista-hasel/haslo/?id=82), mimo zmian dotyczących głównie charakterystyki głównych bohaterów, nadal mogą być odczytane - w duchu psychoanalizy - jako ,studium o dorastaniu do identyfikacji płciowej, oznaczającej zdolność do nawiązania dojrzałej relacji z innym człowiekiem. W tym kontekście istotna jest zwłaszcza złożona symbolika pantofelka" (Rzepnikowska 2017: http://bajka.umk.pl/slownik/listahasel/haslo/?id=82);

2) intertekstualności (otwartość na inne teksty): „Intertekstualność genru wynika więc z tego, że wchodzi on w kontakt $\mathrm{z}$ innymi typami tekstów i podlega ich oddziaływaniom. Intertekstualność genru oznacza jednak i to, że konkretna realizacja danego genru nie jest nigdy prostym powieleniem jakiegoś modelu, ale jest również twórczym jego przekształceniem" (Duszak 1998: 219). Analizowane teksty o Kopciuszku stanowią twórcze przekształcenie wzorca, są przykładem otwarcia tekstu bajki na inne nowe elementy fabularne, które nie zmieniając ani kompozycji, ani nawet wymowy gatunku, twórczo i z humorem go modyfikują, co powoduje, że bajka jest gatunkiem wciąż żywym; 
3) stopniowalności cech, co podkreśla m. in. Bożena Witosz, pisząc: „Przynależność do określonego gatunku ma charakter stopniowalny - konkretny tekst może być postrzegany jako bardziej lub mniej typowy czy wręcz wątpliwy jego reprezentant - pisze Bożena Witosz (Witosz 2001: 70).

Powyższe rozważania prowadzą autorów do wniosku, że przytoczone przykłady - mimo przekształceń - są raczej typowym reprezentantem bajki jako gatunku, i to niezależnie od przyjętej koncepcji teoretycznej.

\section{Kognitywne ujęcie gatunku jako kategorii poznawczej}

Dotychczasowe koncepcje gatunku - jak widać z powyższego skrótowego przedstawienia przeszły znaczącą ewolucję, w której wyróżnić można trzy etapy ${ }^{5}$, ukazujące gatunek odpowiednio jako (i) zamknięty system, (ii) dynamiczną, a więc zmienną, półotwartą strukturę oraz (iii) otwarty komunikat/tekst. Jednocześnie w polskich badaniach genologicznych pojawia się także koncepcja, która zdaje się nawiązywać do ustaleń kognitywistów, czyli ujęcia gatunku jako konstrukcji mentalnej, modelu (schematu, reprezentacji) określonego typu tekstu (Witosz 2004: 44). Jak zatem kognitywiści widzą pojęcie gatunku? Aby próbować odpowiedzieć na to pytanie, aplikujemy teorię prototypów do dyskusji nad pojęciem gatunku/gatunków mowy. Przyjmujemy zatem, że język jest otwartym zbiorem elementów symbolicznych, a nie zamkniętym systemem znaków dowolnych, i że to język jest wypadkową myślenia i doświadczenia, a nie myślenie i doświadczenie pochodnymi języka. Samą zaś teorię prototypów przedstawiamy w świetle najnowszych publikacji czołowego językoznawcykognitywisty Ronalda Langackera (Langacker 2016 i 2017).

Zacznijmy zatem od krótkiej charakterystyki tego, jak Langacker rozumie prototyp. Otóż umieszcza on pojęcie prototypu - zgodnie z całą tradycją badań prowadzonych w ramach teorii prototypów - w kontekście kategoryzacji. I mówi, że w przypadku danej kategorii złożonej, ,przez prototyp można rozumieć bazę [ang. baseline] ${ }^{6}, \mathbf{z}$ której rozwijają się - na zasadzie rozszerzenia, uszczegółowienia i schematyzacji - kolejne warianty" (Langacker 2016: 36; te i inne cytaty i przykłady anglojęzyczne podajemy w naszym tłumaczeniu, P. Ł. i M. W.). Za prototyp w sensie baseline Langacker uznaje na przykład przedmioty fizykalne, które w procesie metaforyzacji służą nam do postrzegania przedmiotów abstrakcyjnych, lub jakąkolwiek normę językową (wtedy odchylenia/odstępstwa od standardu prowadzą do powstawania odmian bazy), czy bieżący stan języka (wtedy zmiany bazy to zmiany językowe). 
Jeśli odniesiemy te ustalenia do naszej dyskusji nad gatunkowością bajki magicznej jako prozatorskiego gatunku folkloru, to otrzymujemy dwie ścieżki poszukiwań badawczych:

i) ścieżka ontologiczna: poszukiwanie odpowiedzi na pytanie, czym jest sama baza gatunkowa (sam prototyp), w odniesieniu zarówno do gatunku mowy jako takiego, jak i do poszczególnych gatunków mowy, oraz

ii) ścieżka epistemologiczna: poszukiwanie odpowiedzi na pytanie, jakie aspekty

ludzkiego poznania motywują przekształcenia bazy gatunkowej i warunkują rozwój danego gatunku mowy.

Te dwie możliwości badawcze można zresztą wyprowadzić z rozważań nad znaczeniem samego terminu baseline, który - przypomnijmy - stanowi dla Langackera zdroworozsądkową wykładnię rozumienia pojęcia prototypu. ${ }^{7}$ Langacker używa baseline przede wszystkim w jego naukowym/akademickim rozumieniu - jako punkt odniesienia i/lub punkt wyjścia (np. wzorcowy pomiar, ustalony fakt, dane wyjściowe), do którego odnoszone są i z którym porównywane są inne stany i procesy w celu ustalenia ich względnej wartości. Oto dwa przykłady zastosowania terminu baseline w języku angielskim (na podstawie zasobów meriam-webster online):

[1] The experiment is meant only to provide a baseline for other studies.

'Eksperyment ma stanowić jedynie punkt wyjścia [baseline] dla innych badań.'

[2] Any year or event we use as the baseline for the Renaissance is going to be at least somewhat arbitrary.

'Każdy rok i każde wydarzenie, jakie moglibyśmy podać za punkt odniesienia [baseline] dla epoki renesansu, będą co najmniej wyborem arbitralnym.'

Wspomniany eksperyment jest baseline w sensie czegoś, od czego należy zacząć, a poszukiwanie baseline dla renesansu oznacza osadzanie renesansu w realiach typowych dla tej epoki. Podobne skojarzenia budzi przyjęcie rozumienia baseline w sensie sportowym - jako linia końcowa placu gry (kortu tenisowego, czy boiska do siatkówki) lub jako wydzielony plac gry (jak w baseballu), poza który gracz nie może wykroczyć. Wtedy otrzymujemy pytanie ontologiczne o prototyp jako normę (lub lepiej: o zakres tej normy), wyjście poza którą grozi utratą dystynktywności gatunku i - ostatecznie - zmianą gatunku. 
Pozornie wydaje się, że referowane wyżej ujęcia strukturalistyczne i funkcjonalne pozwalają na analizy mieszczące się w tak rozumianej ścieżce ontologicznej: Głowiński (1965) mówi o zestawie wskazań, czynników i środków, Trzynadlowski (1962) o ich kontekstowej/sytuacyjnej wariantywności, Duszak (1998) o adaptacyjnych przekształceniach, i w tym wszystkim można widzieć Langackerowski baseline, czyli punkt odniesienia albo punkt wyjścia dla określenia gatunku bajki. Dla naszych tekstów A i B takim punktem odniesienia/wyjścia byłaby zapewne tradycyjna bajka o Kopciuszku, opowieść o służącej wykorzystywanej i pogardzanej przez macochę i przyrodnie siostry, aż do czasu kiedy przy pomocy wróżki jedzie ona na bal u księcia, książę się w niej zakochuje, ona o północy biegnie do domu, przy czym gubi pantofelek, itd. Dopóki pozostajemy w granicach bazy, bez względu na to, czy ta baza to obowiązkowy zbiór cech normatywnych, czy zestaw cech do wyboru, czy jedynie zestaw typu „zrób to sam”, dopóty mamy bajkę (o Kopciuszku).

Ale nie taka jest intencja Langackera, i teorii prototypów osadzonej w kontekście kategoryzacji i metaforyzacji. Baza - baseline - nie jest skończonym, zamkniętym komunikatem (Głowiński), ani nie jest komunikatem otwartym na kolejne wariacje (Trzynadłowski), ani w ogóle nie jest żadnym komunikatem (Skwarczyńska). Baza jest znaną, poznaną, i zapoznaną domeną doświadczenia, która służy do konceptualizowania i wyrażania tego, co w doświadczeniu pojawia się jako nieznane, niepoznane, i niezapoznane. W stosunku do tekstów A i B tradycyjna bajka o Kopciuszku pełni taką samą rolę (domeny wyjściowej), jak w stosunku do domeny czasu pełnią przestrzeń (por. na przestrzeni wieków, za trzy dni, przed dwoma tygodniami), czy pieniądze (czas to pieniądz, zaoszczędzić/tracić czas), a w stosunku do emocji pełnią barwy (zzielenieć z zazdrości, zblednać ze strachu, zaczerwienić się ze wstydu). Tak, jak nie jesteśmy świadomi tego, że myślenie w kategoriach przestrzeni pozwala nam „mierzyć” czas, a myślenie w kategoriach barw pozwala nam „przeżywać” emocje, w podobny sposób nie zdajemy sobie sprawy z tego, że bajka jest namacalnym sposobem „Zwizualizowania” prawd i wartości. To, co odległe, bo pojęciowo abstrakcyjne i złożone (wartości), zostaje wyrażone w postaci tego, co bliskie, czyli znane i/lub obecne (opowiadanie).

Tak oto bajka, gatunek mowy i typ formy językowej w świetle koncepcji strukturalistycznych i funkcjonalnych, w zamyśle kognitywistów staje się kategorią poznawczą i typem konceptualizacji jednych zdarzeń doświadczenia (abstrakcyjnych) za pomocą innych zdarzeń doświadczenia (konkretnych). Nasze teksty A i B pozostałyby bajkami (o Kopciuszku) nawet wtedy, gdybyśmy z nich usunęli imię bohaterki, nie wspomnieli ani 
słowem o macosze, a pantofelek zastąpili smartfonem, tak, jak nie trzeba powtarzać, że czas to pieniądz albo że życie jest podróżą, żeby dać wyraz tym konceptualizacjom. Mówiąc straciłem całe popołudnie nie myślimy przecież o pieniądzach, a mówiąc każdego dnia zbliżam się do ciebie coraz bardziej nie myślimy o podróży, a jednak pieniądze i podróż stanowią konceptualną bazę dla tych wyrażeń.

Z rozlicznych przykładów analitycznych Langackera zwróćmy uwagę na ten odnoszący się do tzw. wyrażeń kotwiczących:

W języku angielskim przyimek i oznaczany przez niego przedmiot zostają z zasady umieszczane w bezpośrednim sąsiedztwie w stosunku do siebie, co nadaje im charakteru wyrazistej frazy rytmicznej (np. with freckles dosł. 'z piegami'). Ta fraza następuje po rzeczowniku (np. with freckles w girl with freckles dosł. 'dziewczyna z piegami'), podczas gdy przymiotnik - podobnie do elementu kotwiczącego (np. that $\mathrm{w}$ that girl) - na ogół występuje przed, a nie po (np. cute $\mathrm{w}$ cute girl 'ładna dziewczyna'). Jednakże, takie prototypowe konstrukcje mają swoje warianty, które stają się możliwe po tym, jak atrybuty prototypowe zostają nadpisane przez inne względy i czynniki. A zatem, angielskie konstrukcje kotwiczące zawierają nie tylko wersję bazową (prototypowa), w której element kotwiczący poprzedza rzeczownik jako taki, ale także bardziej ogólny wariant, w którym zajmuje on pierwsze miejsce w całym wyrażeniu nominalnym (np. that w that cute girl 'ta ładna dziewczyna', czy those jak w those who can afford it 'ci, których na to stać'). Jeśli tak, zamiast czysto strukturalnej segmentacji wyrażenia that cute girl with freckles do postaci (that) (cute girl with freckles), czyli na zasadzie rozłączania elementu kotwiczącego (tu: zaimek wskazujący) od wyrażenia nominalnego, otrzymujemy bardziej naturalny prozodycznie podział na (that cute girl) (with freckles)

Powtórzmy: „konstrukcje (...) zawierają nie tylko wersję bazową (prototypową), (...) ale także bardziej ogólny wariant”. To tak, jakbyśmy powiedzieli - przyjmując, że tradycyjna wersja bajki o Kopciuszku jest prototypowa/bazowa dla wszystkich bajek o Kopciuszku - że bajki o Kopciuszku zawierają nie tylko wersję bazową, ale także bardziej ogólny wariant, który zostaje „nadpisany” przez coś jeszcze niż same relacje między bazą i jej przekształceniami. 


\section{Wnioski}

A zatem sugerujemy, że poszukiwanie koncepcji gatunku mowy (bajki) w kategoriach prototypu rozumianego jako Langackerowski baseline, nie można ograniczać jedynie do ścieżki ontologicznej. Jeśli, jak dowodzimy, gatunek mowy to sposób myślenia o świecie, sposób konceptualizowania prawd i wartości, równie nieodzowne jest studium ścieżki epistemologicznej, a w tym względzie koncepcje strukturalistyczne i funkcjonalistyczne wydają się bezradne. Cała uwaga koncentruje się w nich bowiem na pytaniu, ile z bajki musi być w bajce, żeby bajka była bajką. Tymczasem Langacker, mówiąc o tym, że z prototypu „wyrastają" - w procesie rozszerzenia, uszczegółowienia i schematyzacji - jego warianty i odmiany, zaprasza do pokonania ścieżki epistemologicznej, czyli stwierdzenia, jakie procesy poznawcze, jakie domeny doświadczeniowe, i w jaki sposób pozwalają na rozwój gatunku (mowy) tak, że mimo swojej ewolucji dany gatunek wciąż pozostaje tym samym gatunkiem, a bajka o Kopciuszku pozostaje bajką o Kopciuszku.

Pewną uproszczoną ilustracją tego (epistemologicznego) problemu są dwa z ostatnich filmów Woody Allena: „Blue Jasmine” (2013) i „Irrational Man” (2015) to - jakby powiedział Langacker - rozszerzenia, uszczegółowienia i schematyzacje odpowiednio Tramwaju zwanego pożądaniem Tennessee Williams'a i Zbrodni i kary Fiodora Dostojewskiego. Ale skąd o tym wiemy i dlaczego jesteśmy o tym przekonani, skoro - w przeciwieństwie do naszych bajek A i B - nie tylko realia czasoprzestrzenne i kulturowe zostały zmienione, ale nawet imiona bohaterów? Zastanawianie się, ile Williamsa i ile Dostojewskiego jest w tych dwóch filmach Allena, jest daremnym pokonywaniem ścieżki ontologicznej - trzeba sięgnąć po procesy poznawcze i czynniki doświadczeniowe, które te skojarzenia (między dziełem literackim i dziełem filmowym) warunkują.

Tak, czy inaczej, przyszłość badań nad gatunkami mowy wydaje się mieć związek z pytaniem o to, jak pogodzić „bazowość” prototypu z dynamicznością kategorii, dla której prototyp stanowi baseline, czyli odpowiedzieć jednocześnie na dwa pytania postawione w (i) i (ii) powyżej, ze wskazaniem na to drugie. 


\section{Przypisy}

1 Przyjmując uproszczony model rozwoju współczesnego językoznawstwa (od strukturalizmu poprzez funkcjonalizm do kognitywizmu), przedstawiamy gatunek odpowiednio jako: system, strukturę, komunikat i kategorię poznawczą. Jednakże ze względu na synkretyczny charakter badań językoznawczych (a także na ich interdyscyplinarność oraz zróżnicowanie wynikające z analiz konkretnych baz materiałowych, takich jak teksty folkloru i polityki), bardziej szczegółowa prezentacja wymagałaby przywołania odnośnych metodologii i paradygmatów. Tak czynią Piotr Cap i Urszula Okulska (2013). Omawiają mianowicie: Systemic Functional Linguistics (Halliday), badania nad retoryką (Bazerman), językoznawstwo stosowane (Swales), pragmatykę językoznawczą (Levinson), czy szeroko i wąsko rozumiane badania dyskursu (Fairclough, Barton) (zob. zamieszczona tam bibliografia). W ten sposób przywołani badacze otrzymują interesujący zestaw możliwych - i powiązanych - odczytań/definicji gatunku: jako abstrakcji (p. 3), jako kontekstu sytuacyjnego (p. 4), jako elastycznych makrostruktur (p. 4), jako społecznie warunkowanych ścieżek intertekstualnych (p. 5), czy interpersonalnych ról (p. 6) (Cap, Okulska 2013).

${ }^{2}$ Nie jest naszym celem przedstawienie kompletnego i wyczerpującego stanu polskich badań nad gatunkiem mowy, a zarysowanie tendencji rozwojowych, by odnieść je wybiorczo do tego, jak Langacker rozumie prototyp.

${ }^{3}$ Zob. więcej Wójcicka (2010).

${ }^{4}$ Zob. więcej Wójcicka (2017): http://bajka.umk.pl/slownik/lista-hasel/haslo/?id=222

${ }^{5}$ Gatunek traktowany jest jako kategoria złożona i rozpatrywany w trzech perspektywach: dynamicznej (jako zjawisko komunikacyjne, kulturowe), statycznej (jako typ tekstu, model pozwalający łączyć teksty o podobnych właściwościach) i konkretyzującej (jako zbiór wypowiedzi lub wypowiedź będąca najlepszym egzemplarzem, reprezentantem zbioru) (Wojtak 2004: 16).

${ }^{6}$ Mimo swoich pokaźnych rozmiarów monografia Langacker'a z 2008 roku, uznawana za kompendium jego gramatyki kognitywnej, zawiera zaledwie dwa użycia baseline w porównywalnym znaczeniu, które zostały przetłumaczone w wersji polskiej ([2008]2009) jako standard (s. 492) i podstawa (s. 670). W tym artykule w ich miejsce jako polski odpowiednik baseline proponujemy słowo baza. (Patrz także przypis następny.)

${ }^{7}$ Rozumienie prototypu jako baseline należy uznać za nowe dla Langackera, i cytowanych tu jego prac (2016, 2017). Do tej pory (por. Langacker 2008, i polska wersja [2008]2009) baseline miało znaczenie pasywne i statyczne. Z tego powodu najczęściej występowało z negatywną kwalifikacją. Na przykład, w przypadku tzw. zerowej roli uczestników (,funkcja [która] jest pojęciowo znikoma i niedystynktywna”; 2009: 473), Langacker mówi, że „ta neutralna, peryferyjna [ang. neutral or baseline] rola ogranicza się do danego istnienia, znajdowania się w jakiejś lokalizacji czy wykazywania jakiejś stałej własności” (s. 473). Podobnie rozważając, czym się charakteryzują stwierdzenia (w odróżnieniu do obietnic, czy pytań) Langacker mówi, że są „mdłe”, ponieważ „Samo z siebie stwierdzenie niesie niewiele poza zupełnie podstawowym [ang. baseline] oczekiwaniem (...), że zostanie wysłuchane i zrozumiane" (s. 631). Na marginesie tych dywagacji terminologicznych zwracamy uwagę na to, że trudności ze zrozumieniem baseline jako wykładni prototypu przypominają trudności ze zrozumieniem samego terminu prototype. Pisze o tym Łozowski (2012; tu: 2016: 34): ,[R]ozumienie, jakie Langacker przypisuje terminowi prototype 'prototyp' (...), jest takie, że termin ten nie oznacza pierwszego/pierwotnego przedstawiciela danej kategorii, ale przedstawiciela najlepszego. Gdybyśmy więc intuicyjnie zastosowali termin prototyp do poszukiwań pierwowzoru, czy praprzykładu, homo sapiens, nie mógłby nim zostać nikt z nas, ale mógłby nim być neardentalczyk, jeśli to jego uznamy za pierwszego człowieka myślącego. Podobnie prototypem kategorii PTAKI musiałby zostać - w myśl jednej z teorii o pochodzeniu ptaków - archeopteryks, pochodna dinozaura teropoda, a nie żaden wróbel, szpak, czy gołąb.” 


\section{Bibliografia}

Bachtin, Michaił ([1979] 1986) Estetyka twórczości słownej. [Ėstetika slovesnogo tvorčestva.

Tłum. Danuta Ulicka]. Warszawa: Państwowy Instytut Wydawniczy.

Balcerzan, Edward (1999) „W stroną genologii multimedialnej”. Teksty Drugie, nr 6; 7-24.

Bartmiński, Jerzy (1992) „Tekst folkloru jako przedmiot folklorystyki”. [W:] Henryk

Markiewicz, Janusz Sławiński (red.), Nowe problemy metodologiczne literaturoznawstwa.

Kraków: Wydawnictwo Literackie; 246-271.

Cap, Piotr i Urszula Okulska (2013) „Analyzing genres in political communication. An introduction”. [W:] Piotr Cap, Urszula Okulska (red.), Analyzing Genres in Political Communication. Theory and Practice. Amsterdam/Philadelphia: John Benjamins Publishing Company; 1-26.

Duszak, Anna (1998) Tekst, dyskurs, komunikacja międzykulturowa. Warszawa:

Wydawnictwo Naukowe PWN.

Gajda, Stanisław (2001) „Gatunkowe wzorce wypowiedzi”. [W:] Jerzy Bartmiński (red.), Współczesny język polski. Lublin: Wyd. UMCS; 255-268.

Głowiński, Michał (1967) „Gatunek literackie i problemy poetyki historycznej”. [W:] Maria Janion, Aniela Piorunowa (red.), Proces historyczny w literaturze i sztuce. Warszawa: Państwowy Instytut Wydawniczy; 84-98.

Grochowski, Grzegorz (2004) „Czy istnieje tekst poza gatunkiem?”. [W:] Danuta Ostaszewska (red.), Gatunki mowy i ich ewolucja, t. 2 Tekst a gatunek. Katowice: Wyd. UŚ; 20-28.

Langacker, Ronald W. (2008). Cognitive Grammar. A Basic Introduction. Oxford: Oxford University Press.

Langacker, Ronald W. (2009). Gramatyka kognitywna. Wprowadzenie [Cognitive

Grammar. A Basic Introduction. Tłum. Elżbieta Tabakowska i inni] Kraków:

Universitas.

Langacker, Ronald W. (2016) Nominal Structure in Cognitive Grammar. The Lublin

Lectures. Edited by Adam Głaz, Hubert Kowalewski and Przemysław Łozowski (red.).

Lublin: Maria Curie-Skłodowska University Press.

Langacker, Ronald W. (2017), “The functions of trees". [W:] Przemysław Łozowski i Adam Głaz (red.), Route 66: from Deep Structures to Surface Meanings. A Festschrift for Henryk Kardela on his $66^{\text {th }}$ Birthday. Lublin: Maria Curie-Skłodowska Press; 73-92. 
Łozowski, Przemysław (2016) „W poszukiwaniu terminologii językoznawczej: system w czasach symbolu czy symbol na potrzeby systemu?”, Pótrocznik Językoznawczy Tertium 1/1\&2)/2016; 29-39. DOI: http://dx.doi.org/10.7592/Tertium2016.1.1\&2.XXX

Ługowska, Jolanta (1981) Ludowa bajka magiczna jako tworzywo literatury. Wrocław:

Zakład Narodowy im. Ossolińskich.

Ługowska, Jolanta (1993) W świecie ludowych opowiadań. Teksty, gatunki, intencje narracyjne. Wrocław: Wyd. Uniwersytetu Wrocławskiego.

Propp, Władimir ([1928]1976) Morfologia bajki [Morfołogija skazki, tłum. W. WojtyłaZagórska]. Warszawa: Książka i Wiedza.

Propp, Władimir (2000) Nie tylko bajka, [wybór i tłumaczenie Danuta Ulicka]. Warszawa: Wydawnictwo Naukowe PWN.

Rzepnikowska, Iwona (2017) „Kopciuszek” http://bajka.umk.pl/slownik/listahasel/haslo/?id=82

Skwarczyńska, Stefania (1954) Wstęp do nauki o literaturze, t. 1. Warszawa: Instytut Wydawniczy „Pax”.

Trzynadlowski, Jan (1983) „Zmienność i stałość gatunku literackiego”. [W:] Ewa MiodońskaBrokes, Adam Kulawik, Marian Tatara (red.) Genologia polska. Wybór tekstów, Warszawa: Wydawnictwo Naukowe PWN; 38-46.

Witosz, Bożena (2001) „, Gatunek - sporny (?) problem współczesnej refleksji tekstologicznej”. Teksty Drugie, nr 5, 67-85.

Witosz, Bożena (2004) ,, Tekst i/a gatunek. Jeden czy dwa modele? ’. [W:] Danuta Ostaszewska (red.) Gatunki mowy i ich ewolucja, t. 2 Tekst a gatunek. Katowice: Wyd. UŚ; 40-49.

Wojtak, Maria (2004) „Wzorce gatunkowe wypowiedzi a realizacje tekstowe”. [W:] Danuta Ostaszewska (red.) Gatunki mowy i ich ewolucja, t. 2 Tekst a gatunek. Katowice: Wyd. UŚ; 29-39.

Wójcicka, Marta (2010) Dawno to temu, już bardzo dawno... Formuly ramowe $w$ tekstach polskiej prozy ludowej, Lublin: Wyd. UMCS.

Wójcicka, Marta (2017) „Bajka magiczna”. http://bajka.umk.pl/slownik/listahasel/haslo/?id=222

Żydek-Bednarczuk, Urszula (2001) „Typy, odmiany, klasy... tekstów. W poszukiwaniu kryteriów”. [W:] Bożena Witosz (red.) Stylistyka a pragmatyka. Katowice: Wyd. UŚ; 114125. 


\section{Źródla internetowe}

http://sciaga.pl/tekst/89555-90-nowoczesna_wersja_kopciuszka

meriam-webster online $=$ https://www.merriam-webster.com/dictionary/baseline

http://www.etykawszkole.pl/baza-wiedzy-/materiay-edukacyjne/280-bajka-o-kociuszku-

cakiem-inaczej 